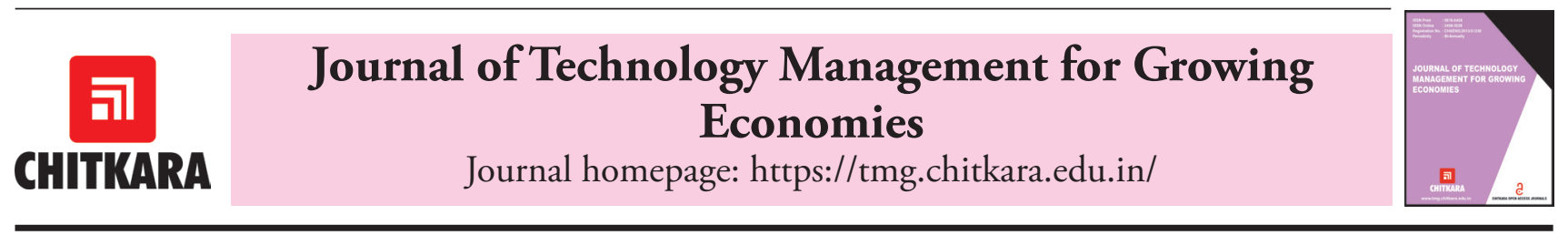

\title{
Online Platforms for Teaching-Learning in View of COVID - 2019
}

\author{
Ashok Kumar Sahoo1 ${ }^{10}$, Pradeepta Kumar Sarangi² and Rajeev Gupta ${ }^{3}$ \\ ${ }^{1}$ Department of Computer Science \& Engineering, Graphic Era Hill University, Dehradun, Uttarakhand-248171, India \\ ${ }^{2}$ Chitkara University Institute of Engineering and Technology, Chitkara University, Punjab-140401, India \\ ${ }^{3}$ School of Computing, Graphic Era Hill University, Dehradun, Uttarakhand-248171, India \\ 2pradeepta.sarangi@chitkara.edu.in \\ 3grejeev63@gmail.com \\ 1ashoksahoo2000@yahoo.com (Corresponding Author)
}

\section{ARTICLE INFORMATION}

Received: July 02, 2020

Revised: September 14, 2020

Accepted: September 26, 2020

Published Online: November 16, 2020

Keywords:

ICT, Bloom's Taxonomy, Podcast, Multimedia,

Virtual Classroom, Teleconferencing

\section{ABSTRACT}

In almost all countries, classroom teaching has been suspended from mid March 2020 and currently no fresh dates have been announced by Governments to start the date. In view of this, almost all educational institutions in India are offering a variety of alternative teaching learning platforms to their students, whether Government run Institutions or privately run Institutions. The Institutions also conducted or planning to conduct their internal or final examinations through various platforms. In this paper, a number of online options for teaching and evaluation are discussed. The study is limited to India and discussion of software based platforms, whether web based or mobile apps based are considered. The research is limited to higher education sector specifically in under graduate engineering education.

\section{Introduction}

The aim of the education is to enable the learner to apply, analyse, synthesize and evaluate the basic concept of education in classroom settings according to Blooms taxonomy (Agarwal, 2019). The shape of education has changed a lot since its inception. Modern technology has replaced the traditional books. In this age of liberalization, privatization and globalization to enhance the quality of teacher education; powerful pedagogical are strategies required to acquire the higher order thinking. This could be supported by integration of Information Communication Technology (ICT). Modern technology which consists of synchronous and asynchronous media made education which is said to be out of box type of form in recent days. Through its access we can't only meet the global requirements but also can exchange our ideas knowledge as well. This has made even far distance places near to our disposition. After using ICT, the classes have become more decorative, lively and interesting.

In order to make interactive environment to its best, it is necessary that all persons engaged in the educational sector should first understand the mechanism of technology and they should also know what and how latest trends can be incorporated to make environment interactive while teaching. The present study aims to give a capturing glance on the integrating ICT in teaching-learning pedagogy which will not only be fruitful for interactive learning but also seems helpful for self-learning. These trends will include use of podcasting, multimedia products, concept of virtual classrooms, use of teleconferencing, web-based learning formats and what contribution we are getting from government for ICT access and its dissemination. The study also aims to discuss and analyse about various ICT initiatives started by Government of India for integrating ICT in educational framework. These initiatives are imparting a new dimension in various aspects of teaching-learning process.

\section{Audio Based Learning Platforms}

Podcasting (Ho, Chou \& Fang, 2016) is derived from two words, first one, Apple's iPod and the second term Broadcasting. It is a form of audio files to be broadcasted in order to convey some educational document. There are a large number of podcast systems available almost in all fields. Our focus is on learning platform podcasts and hence we will limit our study to example podcasting systems like 
Pinna, Podcasts, GarageBand, Science Friday, Listenwise, StoryCorps, Soundtrap, Anchor, Radio Rookies, YR Media, HowStuffWorks, NPR (Borderland, News, One), and Science Update.

Pinna podcast (Pinna, 2020) is an online audio podcast system designed for students from pre nursery to class 6 . It is available free for first two months and available at $\$ 7.99$ per month thereafter for students and provides various audio related knowledge platform for science, mysteries and interactive game shows.

Podcast is a free online podcast learning system available in Apple platform. It is suitable for classes up to 12 standards. The subjects covered by this are Arts, Communication \& Collaboration. This podcast system is designed to support students and teachers in addition to their traditional learning systems and can be replacement of traditional class room teaching methodology.

GarageBand is a podcast system which can be run on Apple's Mac operating system (MacOS) and Apple's iPad operating system (iOS). It is designed to use and create music or podcasts. The users of this podcast system can create many tracks using MIDI keyboards, a bunch of instrumental effects simultaneously and voice recordings. It has a complete sound library for instruments, presets for voice and guitar, percussionists and drummers.

Science Friday (Science Friday Inc, 2019) is another popular podcast providing information about scientists to public radio listeners. They are producing digital videos, award-winning podcasts, educational resources for teachers both formal and informal educators, original web articles and much more. This is a non-profit organization producing and providing access to scientific knowledge.

Listenwise (Harness the Power of Listening, 2020) provides valuable knowledge for improving comprehension, relistening, or citing evidence. Students can access by listening comprehension by help of idea and inferencing. Comprehensive scores are provided to individual students and teachers for more improvement in the topic. According to levels of listening comprehension, diverse learners can select right podcasts to measure lexile audio. It provides podcasts on social studies, science, current events and literature.

Story Corps (StoryCorps, 2020) is an independently funded organization primarily dependent on instructional support for their survival. It is incorporated in the year 2003 in United States. The primary focus of the organization is collecting, preserving and sharing of citizen stories. The intension of the learning platform is to teach the value of listening.

Soundtrap (Your everywhere studio, 2020) is a podcast system developed for music makers, story tellers and education. With the feature of interactive transcript, automatically record; transcribe of voice is possible. Editing of recording is also possible and the edited recordings can be uploaded to spotify and improvement of discoverability or it can be distributed.

Anchor (Anchor, 2020) is a podcast designed for unlimited free hosting, distribution, monetizing, podcasting with friends, straightforward analytics, recording from anywhere, episode builder, editing and creation tools. Other podcast documents can be converted into Anchor podcast documents and transcribed videos can be produced. It provides services free of cost to its subscribers.

Radio Rookies (Radio Rookies, 2020) has been continuously conducting workshops across New York since 1999 training and tools to people to tell their own stories. The following are the popular stories created by the organization namely: "Expecting the Unexpected: Graduating High School During a Pandemic", "America For Someone Like Me", "When We See Each Other: Black Americans, African Immigrants", "East Village Workshop", "Social Media When You're a Refugee", "Making Friends When You're Shy", "Trying to Graduate From High School at 21", "The Changing Meaning of Gender Across Generations", "One Immigrant's Anxiety in Trump's America" and "She Wants to be Treated Equally in the Kitchen".

YR Media (Formerly Youth Radio) (YR Media, 2020) is a national network in USA of young journalists and artists. It is working since last 25 years as a non-profit production company for future generations to build critical skills in media, art and journalism. The platform in YR Media is specifically designed for students, activists, writers, parents and teachers.

How Stuff Works (Garden, 2020) is providing more than 750 podcasts for business, sports, spirituality, entertainment, technology, comedy, family and crime. The network is also home to long-running fan-favorites such as Stuff You Should Know and Stuff You Missed in History Class, and instant hits like The Ron Burgundy Podcast and Disgrace land.

NPR (National Public Radio) (Boarderland, NPR, 2020 ) is established as a non-profit organization to create awareness among general public. It is connecting to millions of USA people online and individually to create new ideas. Through the NPR network, it is wide spreading stories from local level to global level.

Science Update (The Science Radio News Feature of the American Association for the Advancement of Science, 2020) is featuring latest discoveries in medicine, technology and science. It is managed by world's largest common science society. It was established in 1988 and won a number of awards. Listeners can contact with their dedicated toll-free telephone lines or can use online form to access podcasts related to science. To access free radio programming lineup users can visit (Entertaining and Informative, 2020). Nationwide science update is available for radio listeners also. 


\section{Multimedia Based Learning Apps}

Multimedia products (Schank, Korcuska \& Jona, 1995) can be categorized into text and graphics mode, podcasts, video and online products. Further text and graphics can be delivered through slideshows or presentations, prezi, diagrams and infographics. We have already discussed a lot about podcasts and examples of podcast systems. In video type multimedia products the available options are lecture capture, talking head, screen capture, animation and glass screen. Other modes of multimedia teaching technologies involve various dedicated websites and interactive mobile applications, virtual classrooms, teleconferencing.

Slideshows or presentations are the most popular platform for technology driven teaching learning during 1990-2000. It has features like, text design, image drawing and embedding, audio and video embedding and excellent visual presentation. It is considered to be far better than that of blackboard or white board with coloured marker based teaching. It has several advantages as compared to traditional methods including clarity of presentation and time saving.

However, it has a number of limitations also including proper synchronization between teacher and learner. Most popular presentation software's are Microsoft Power Point, Prezi, Capterra Diagrams and infographics developed by many software vendors.

Due to technological advantages and availability of Internet in many communicating devices (Rus et al., 2019) like desktops, laptops, palmtops and mobile phones, there is a complete paradigm shift of device based learning platforms. We will discuss some of the freeware in this field and some of the powerful software which are currently in use. A comprehensive comparison between modern learning apps is presented in Table 1 .

Table 1: Pros and cons of various modern learning platforms.

\begin{tabular}{|c|c|c|c|}
\hline Platform & Op. System & Pros & Cons \\
\hline Zoom & iOS, Android & $\begin{array}{l}\text { Screen can be used for many functions } \\
\text { simultaneously, Many calendars can be connected, } \\
\text { and each user can be accessible to annotation } \\
\text { tools, more emphasis on security aspects. }\end{array}$ & $\begin{array}{l}\text { Limited chat options available, the app can } \\
\text { be integrated with participants area, user } \\
\text { experience still needs a lot of improvement, } \\
\text { annotation tools cannot be used in entire } \\
\text { existing range. }\end{array}$ \\
\hline Kahoot! & iOS, Android & $\begin{array}{l}\text { Strong student engagement, Examination system } \\
\text { is very strong as compared to others, Formative } \\
\text { assessment is very easy for teachers, existing } \\
\text { classrooms are usable, Platform is very easy to } \\
\text { acquaintances, and technology integration is a } \\
\text { great feature. }\end{array}$ & $\begin{array}{l}\text { Tracking of student progress is hard, Username } \\
\text { and password problem faced by students and } \\
\text { teachers, very tedious job of managing student } \\
\text { evaluation part. }\end{array}$ \\
\hline Seesaw & $\begin{array}{l}\text { iOS, Android, } \\
\text { Amazon }\end{array}$ & $\begin{array}{l}\text { Ease of navigation of dashboard for teachers, } \\
\text { students are able to showcase their progress in any } \\
\text { multimedia form, out of box thinking is possible, } \\
\text { real time or multiprocessing tasks are possible }\end{array}$ & $\begin{array}{l}\text { Classroom single and multiple setting is tedious, } \\
\text { not for higher education system, notes can } \\
\text { does not have formatting capabilities, log off } \\
\text { problem (uncompleted task is to be start afresh } \\
\text { after logout) }\end{array}$ \\
\hline $\begin{array}{l}\text { Google } \\
\text { Classroom }\end{array}$ & iOS, Android & $\begin{array}{l}\text { Accessible from every type of devices } \\
\text { and platforms, sharing of resources and } \\
\text { communication is very effective, Feedback system } \\
\text { is very strong, true replacement of paper, interface } \\
\text { is clean and user friendly, suitable for all types of } \\
\text { education. }\end{array}$ & $\begin{array}{l}\text { Managing account is difficult, integration with } \\
\text { other systems is tedious, limited automatic } \\
\text { updates, problems in editing, and Impersonal, } \\
\text { automated quiz and tests are not effective. }\end{array}$ \\
\hline Remind & iOS, Android & $\begin{array}{l}\text { Document and message sharing with parents, } \\
\text { schedule announcement is possible, multiple } \\
\text { groups and classes can be set up, supports } \\
\text { unlimited class size, governs by rules and } \\
\text { regulations, ease of use and privacy. }\end{array}$ & $\begin{array}{l}\text { Text messages can be misinterpreted, No login } \\
\text { required, accessibility is some problematic, } \\
\text { unreliable access on mobile phones, unnecessary } \\
\text { phone calls and messages to be received from } \\
\text { Remind. }\end{array}$ \\
\hline Classtree & iOS, Android & $\begin{array}{l}\text { Parents need to sign to access the contents, } \\
\text { tracking of student progress is better, supports } \\
\text { multiple file type, independent learning possible. }\end{array}$ & $\begin{array}{l}\text { It is not a freeware, Out-of-date contents } \\
\text { available; It is behaving like an administrative } \\
\text { tool and really not helpful for teachers, available } \\
\text { only for students up to class } 12 \text {. }\end{array}$ \\
\hline
\end{tabular}




\begin{tabular}{|l|l|l|l|}
\hline Dropbox & iOS, Android & $\begin{array}{l}\text { Backup facility is better for protection of } \\
\text { documents, best feedback facility, provides } \\
\text { sufficient storage space for all documents, } \\
\text { synchronization of local computer resources with } \\
\text { Drop box. }\end{array}$ & $\begin{array}{l}\text { Very costly in terms use, provides low quality } \\
\text { previews, mobile version is not flexible, unable } \\
\text { to read all types of files, administrative rights } \\
\text { related issues. Instructions provided in home } \\
\text { page are not very helpful. }\end{array}$ \\
\hline $\begin{array}{l}\text { Microsoft } \\
\text { Teams }\end{array}$ & $\begin{array}{l}\text { iOS, Android, } \\
\text { Windows }\end{array}$ & $\begin{array}{l}\text { Communication enrichment and productivity } \\
\text { gains, focus on work only platform, better } \\
\text { transparency, easy to use the digital platform, } \\
\text { adding members is very easy. }\end{array}$ & $\begin{array}{l}\text { Transition from outlook is very difficult, users } \\
\text { may confuse by structure of files, sub-optimal } \\
\text { meeting experience, setting permissions is } \\
\text { tedious, provides very limited flexibility. }\end{array}$ \\
\hline TED-Ed & iOS, Android & $\begin{array}{l}\text { Good animation tools, The contents are } \\
\text { informative, fun and interesting, free for students } \\
\text { and teachers, provide flipped type of classroom } \\
\text { approach, and also provide synthesizing, analysing } \\
\text { and problem-solving approach. }\end{array}$ & $\begin{array}{l}\text { Other than video facility is not so promising, } \\
\text { community ideas cannot be exchanged, might } \\
\text { be addiction type of experience for users, } \\
\text { not suitable for formal teaching approach, } \\
\text { examination and evaluation part is somehow } \\
\text { missing. }\end{array}$ \\
\hline Moodle & iOS, Ubuntu, \\
Windows & $\begin{array}{l}\text { Function, simple and easy to use platform, } \\
\text { uploading and downloading features, Assessment } \\
\text { part is very impressive, generating reports is good, } \\
\text { restore and backup features for teachers is good, } \\
\text { learners profile management is excellent. }\end{array}$ & $\begin{array}{l}\text { Videoconferencing facilities is of great concern, } \\
\text { Chatting facility is also another concern, } \\
\text { immediate data analysis part is missing, many } \\
\text { interesting hidden features are present but } \\
\text { training is required, poor mobile based options, } \\
\text { slow server speed, scheduling management can } \\
\text { be enhanced. }\end{array}$ \\
\hline
\end{tabular}

\section{Conclusions}

We have discussed various ways of technology based teaching in this study starting from audio, text, non-interactive multimedia, interactive multimedia and other forms of interactive media. If we can categorize them, some of them are suitable for kids, some of the technology suitable caters up to secondary education level (standard 10), and others are suitable for higher studies. Some of the learning platforms are really commendable and ready to replace class room teaching. Almost all platforms support examination and evaluation part also. In some situations, people are having no other option (like now a days due to COVID-19 and government restrictions in many countries to shut down educational institutions) but only solution is to use one of the above platforms. However, there are a lot of concerns from learners and teachers point of view which cannot be avoided. One thing is very evident that all platforms need either Internet or some kind of broadcasting system like radio and television systems. It is not a concern in developed countries, but it cannot be avoided in developing and underdeveloped countries where communication channels including Internet and electricity are major concerns. Also due to geographical conditions and population density in hilly areas or areas with lack of analog or digital communication and electricity, it is practically impossible to replace classroom teaching. Secondly, the problem of synchronization is also another big concern. Synchronization means, the teaching-learning tuning between teacher and scholars. The teachers continuously monitor the progress of leaning and attention of scholars during classroom teaching. The teaching platforms can provide very good content, knowledge and visualization, but it is for the learners that actually they are getting the contents as one way communication like broadcasting systems (only a receiver of information content and store it for future use). The information received is expected to understand, memorize and to apply in practice but is up to the learner whether he/ she is actually learning or only receiving the information and keep it aside for future learning. Third point is whether the platform is free to use or it is required to purchase. If it is freely available, there are a number of concerns. Two primary concerns are recognition/acceptance of the freely available learning platforms by government and educational agencies legally or as per law and fear of leaking of personal data. Finally, security in these systems is of big concern. Because of personal email addresses, telephone numbers and cell phone numbers are used in these systems to identify persons using these platforms, hence this precious information can be used by hackers to troublesome the users.

\section{References}

Agarwal, P.K. (2019). Retrieval practice \& Bloom's taxonomy: Do students need fact knowledge before higher order learning? Journal of Educational Psychology, 111(2), 189-209. https://doi.org/10.1037/edu0000282

Anchor, (2020). Anchor - The easiest way to make a podcast. Retrieved on May, 2020 from https://anchor.fm 
Boarderland, NPR (2020). National Public Radio: News \& Analysis, World, US, Music \& Arts. Retrieved on June, 2020 from https://apps.npr.org/borderland/

Entertaining and Informative (2020). Retrieved on May, 2020 from www.scienceupdate.com/stations

Garden, H. (2020). HowStuffWorks - Learn How Everything Works! https://www.howstuffworks.com/ (Accessed: July 2020)

Harness the Power of Listening, (2020). Want good listeners? Tell a great Story! Retrieved from https://listenwise.com/educational_podcasts

Ho, C.-T.B., Chou, Y.-H.D., \& Fang, H.-Y.V. (2016). Technology adoption of podcast in language learning: Using Taiwan and China as examples. International Journal of e-Education, e-Business, e-Management and e-Learning, 6(1), 1-12. https://doi.org/10.17706/ ijeeee.2016.6.1.1-12

Pinna, (2020). Kick off the school year with screen-free audio that Entertains \& Educates. Retrieved on May 18, 2020 from https://pinna.fm/

Radio Rookies | WNYC | New York Public Radio, Podcasts, Live Streaming Radio, News, (2020). We bring you content to satisfy all of your curiosities. Life, arts, news, politics, entertainment, food. Everything. (2020), Retrieved from https://www.wnyc.org/shows/rookies
Rus, G.M., Dulamă, M.E., Ursu, C.D., Colcer, A.M., Ilovan, O.R., Jucu, I.S., \& Horvath, C. (2019). Online Apps, Web Sources and Electronic Devices: Learning through Discovery about ValeaIerii [Iara Valley]. In Proceeding of the 14th International Conference on Virtual Learning, 110-119.

Schank, R.C., Korcuska, M., \& Jona, M. (1995). Multimedia applications for education and training: revolution or red herring? ACM Computing Surveys (CSUR), 27(4), 633-635. https://doi.org/10.1145/234782.234809

Science Friday Inc, (2019). Science Friday Podcasts. Retrieved on May, 2020 from http://www.sciencefriday.com

Science Update : The Science Radio News Feature of the American Association for the Advancement of Science (2020). Retrieved on July, 2020 from https://www. scienceupdate.com/podcasts/

StoryCorps - Stories from people of all backgrounds and beliefs. Retrieved on May, 2020 from https://storycorps.org

Your everywhere studio, (2020). Soundtrap - Make music online. Retrieved on May, 2020 from https://www.soundtrap.com

Yr Media (2020). https://yr.media/ (Accessed on 25 May 2020)
旬

\section{CHITKARA}

\section{Journal of Technology Management for Growing Economies}

Chitkara University, Saraswati Kendra, SCO 160-161, Sector 9-C, Chandigarh, 160009, India

\section{Volume -11, Issue-2}

October 2020

ISSN 2456-3226

Copyright: [@2020 Ashok Kumar Sahoo et al.] This is an Open Access article published in Journal of Technology Management for Growing Economies by Chitkara University Publications. It is published with a Creative Commons Attribution- CC-BY 4.0 International License. This license permits unrestricted use, distribution, and reproduction in any medium, provided the original author and source are credited. 